\title{
IMPROVING THE PRODUCTIVITY OF SOLAR STILL BY USING TILTED WICK
}

\author{
Abdel-Salam, M. F.*
}

\section{ABSTRACT}

The objective of this study was to increase the performance and productivity of the solar still to use the distillate water for drinking and hydroponic .Fresh water shortages are rapidly becoming a critical problem in many areas of the world. Such a crisis seriously affects both the industrial and agricultural sectors and adversely affects human life. Therefore, the desalination water that uses solar energy is considered the best solution for solving this problem. Solar still was designed as a rectangular basin with dimensions of 100, 100, and $7.5 \mathrm{~cm}$ for length, width, and height respectively. This still was locally made up of $3 \mathrm{~mm}$ thick galvanized iron (GI) steels. Research experiment was statistically designed and practically applied at the Solar Energy Laboratory, Dept. of Agric. Eng., Fac. of Agric., Ain Shams University, Cairo $\left(\varphi=30^{\circ} \mathrm{N}\right)$. The results explained that the maximum amount of distillate water rate was $5210 \mathrm{~mL} / \mathrm{h}$ at water salinity at $15000 \mathrm{ppm}$ in April. While the minimum value of distillate water rate was $2468 \mathrm{~mL} / \mathrm{h}$ at salinity $35000 \mathrm{ppm}$ in January. The average of distillate water in April was $5044 \mathrm{~mL}$ while, the average of distillate water in January was 2595. It is recommended that use a solar still with tilted wick because it is cheap, easy to maintain and gives high efficiency.

Keywords: Solar desalination; Solar still; Tilted wick; Active solar stills.

\section{1-INTRODUCTION}

$\mathrm{M}$ athematically, $97 \%$ of the water in the world is located in the ocean, approximately $2 \%$ of the water in the world is stored as ice in polar region, and $1 \%$ is potable water available for the need of the animals, plants and human life on earth Gupta et al. (2013). Based on the purpose of use, water resources were classified into specific grades. The first grade is established household purposes, safe drinking and a number of application industries.

\footnotetext{
*Assistant Prof. of Agric. Eng., Fac. Of Agric., Ain Shams Univ.
} 
This water category has a salinity of 5 to $1000 \mathrm{ppm}$. This kind of water is in lakes and rivers and can be achieved industrial desalination processes .In large cities, various levels of water salinity are used, where water with salinity below $150 \mathrm{ppm}$ is used for drinking while higher salinity water of up 1000ppm is used for various household applications. This proved to be more effective because the average per capita consumption of the low salinity drinking water $(150 \mathrm{ppm})$ is limited to 2 liter /day. More over the per person consumption ratio for other household uses is 200-400 liters / day, that is used for cleaning, cooking, washing, gardening, and other purposes, El-Dessouky and Ettouney (2002).

Renewable energy is the alternative solution to the decreasing reserves of fossil fuels. Total worldwide renewable energy desalination installations amount to capacities less than $1 \%$ of that of traditional fossil fuel desalination plants. This is due to the high maintenance and capital costs required via renewable energy, making these desalination plants. Noncompetitive with traditional fuel desalination plants, E. Delyannis (2003).

Abd-El-Salam (1998) mentioned that the use of black muslin absorbed the sea water and increased the sea water diffusion surface area. The result showed that the distilled water quantity in the summer and winter season were 1.33 and 2.89 liter respectively.

Kabeel and El-Agouz (2011) It was found that the use of single-effect solar distillers increases the efficiency from 30 to $40 \%$. Since the daily production of fresh water needed by humans between 2 liters to 8 liters per person and the requirements of drinking water is ideal for 5 liters per person per day and therefore need a solar distillation area Approximately 2 square meters per person.

Hansen and Murugavel (2017) studied the engineering effect of solar absorption plate Fins with a hot water tank compared to the traditional solar system and achieved a high productivity of $74.5 \%$ than the use of traditional solar energy.

Mamlook and Badran (2007) stated that the major factors affecting solar still production are wind speed, ambient temperature, solar intensity, coupled with collector, salt concentration and water depth. These factors 
it is advisable for this factor to be given highest priority for enhancing the solar still productivity.

Murugavel and Srithar (2011) mentioned that solar still is considered one of the most important solutions to overcome the problem of water in remote areas. This device is not popular because of its productivity is low. So we used of solar still with tilted wick a layer of water with wick material in the basin will increase the evaporation area and enhance the production.

Jani and Modi (2018) reviewed the varies ways of increasing the rate of heat transfer in solar still (through using wick material, Nano fluid, Extended and micro fins); and suggested the provision of fins Along with auxiliary systems (external condenser, heat exchanger, mini Solar pond) in solar still as a promising configuration for boosting the Distilled water output.

El-Naggar et al. (2016) evaluated the theoretical and experimental performance of passive solar still and still with strip fins. They have deduced that convective heat transfer coefficient raised by 3.6 times compared to passive solar still.

Sadhana et al. (2015) attempted to increases the heat transfer rate from still to water using fins appended on absorber plate and got the $18 \%$ higher distillate.

Alaian et al. (2016 studied the pin finned wick surface effect on the single slope solar still performance and obtained the efficiency of the system 55\% with $23 \%$ higher yield.

Velmurugan et al. (2009) used a stepped still and a settling tank to desalinate the textile effluent. A maximum raise in production of $98 \%$ is obtained in stepped solar still when sponge, fin, and pebbles are used in this still. A weir-type cascade solar still, integrated with latent heat thermal energy storage system, was designed with the view of increasing productivity.

Kabeel (2009) it is noted that tilted wick solar still types have some advantages over the fixed type for their high performance in distillation 
when conducting a pilot study. There was an increase in the production of distilled water by $20 \%$ to $50 \%$ compared to the normal type at experimental conditions.

Yazan and Madhar (2012) design a pyramid shaped solar still with three different levels of brine depth of 4,8,10 cm. Two levels of water salinity of $15000 \mathrm{ppm}$ and $35000 \mathrm{ppm}$ with three different treatments of without material, black cubes of sponge and black stones. The results showed that around the noon hour, using the black sponge cubes at water depth of 4 $\mathrm{cm}$ and water salinity of $15000 \mathrm{ppm}$ gave the highest still instantaneous efficiency.

\section{The aims of this research are:}

1. Increasing the productivity of fresh water by using tilted wick in solar still.

2. Study the effect of some factors on the solar desalination processes which include solar intensity, wind speed, air temperature, air humidity, heat losses and thermal efficiency

3. Increasing the solar still efficiency.

\section{2-MATERIALS AND METHODS}

2.1.Solar design and fabricatio: Solar still system was geometrically designed amd locally manufacture. This system consistis of water tank, rectangular still basin, and storage bottle, Fig. (1). The still basin was made up of $2 \mathrm{~mm}$ thick galvanized iron (GI) steels with dimensions of 100,100 , and $7.5 \mathrm{~cm}$ for length, width, and height respectively. The basin still was covered with $4 \mathrm{~mm}$ thick glass sheet. This basin was installed on steel frame with $30^{\circ}$ inclined angle, Fig. (2).

\subsection{Instrumentation and measurements:}

A data logger with 8 ports used to measure the temperature using a thermocouple (type K) sensor. It measures the temperature every 15 minutes (water temperature, wick temperature, the temperature of the gap between the cover of the glass and the base of the still, internal glass, and external glass temperature), Fig. (3). 

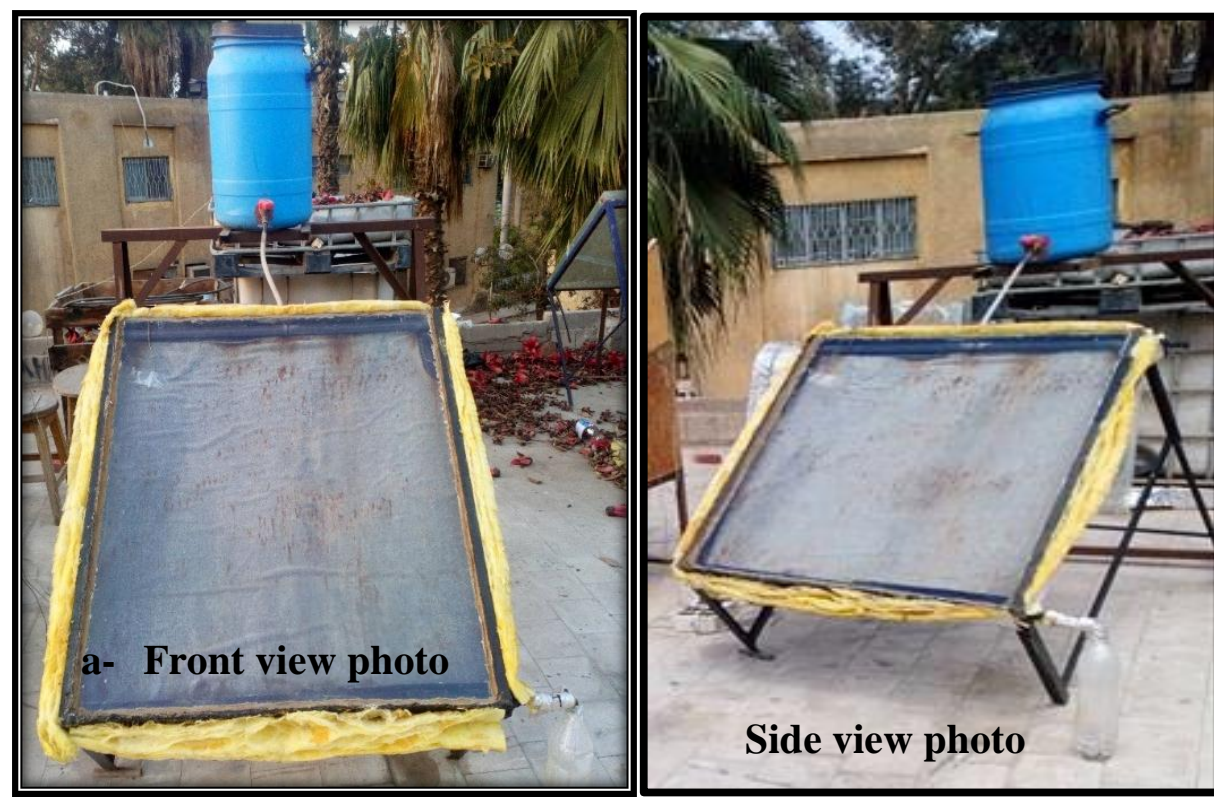

Side view photo

Fig. (2): Two photo of the designed solar still system

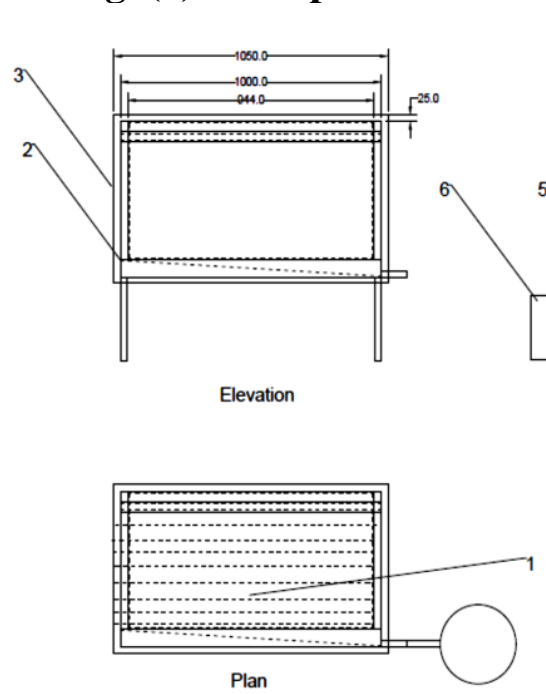

Fig. (2): Shows that an elevation, side view and plan of th solar still

\begin{tabular}{|l|l|}
\hline Part name & No. off \\
\hline Wick & 1 \\
\hline Galvanized iron & 2 \\
\hline Glass wool & 3 \\
\hline Inlet pipe & 4 \\
\hline Outlet pipe & 5 \\
\hline Tank of distillate water & 6 \\
\hline
\end{tabular}

All dimention . mm scale 1:1 


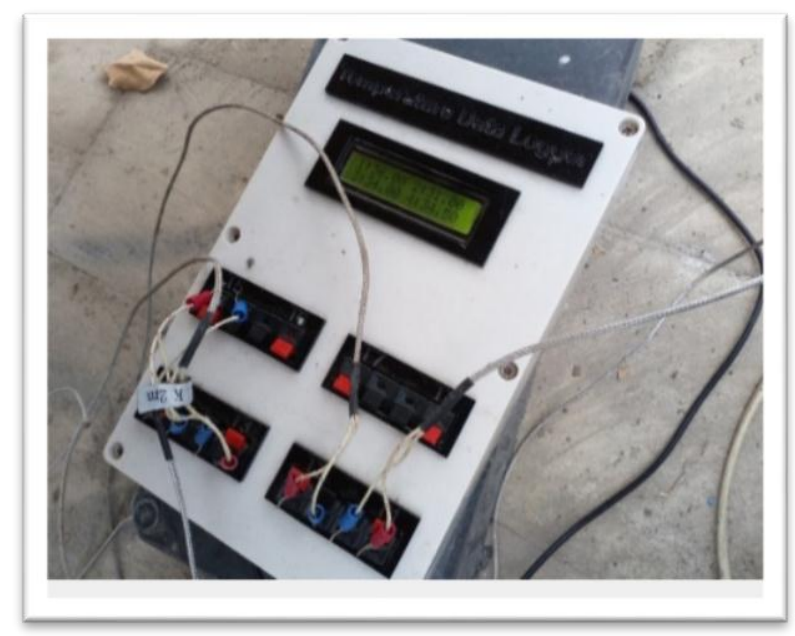

Fig. (3): Temperature data logger.

\section{Thermometer type -k:}

The ambient temperature was measured by thermocouples (type $\mathrm{k}$ ) "Temperature Range: $-50{ }^{\circ} \mathrm{C}$ to $+750{ }^{\circ} \mathrm{C}$ and Accuracy: $-50{ }^{\circ} \mathrm{C}$ to 199.9 ${ }^{\circ} \mathrm{C}\left( \pm 2{ }^{\circ} \mathrm{C}\right)$ with 0.1 Resolution". These thermocouples were connected to digital thermometer $\left(\mathrm{DM} 6801 \mathrm{~A}^{+}\right)$. The temperature was read every 15 minutes as shown Fig. (4). the solar radiation was measured by solar power meter (Accuracy: $\pm 10 \mathrm{~W} / \mathrm{m} 2$. Range: $1999 \mathrm{~W} / \mathrm{m}$. Resolution: 1 W/m2) every 15 minutes, Fig. (5).

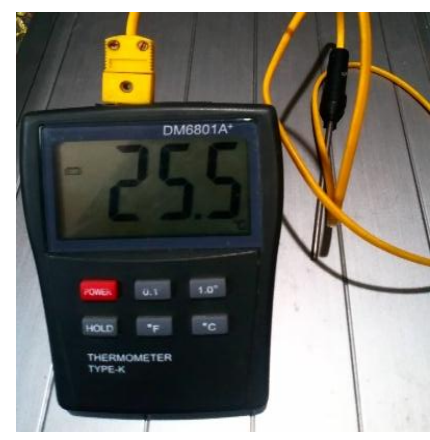

Fig. (4): Thermometer type -k.

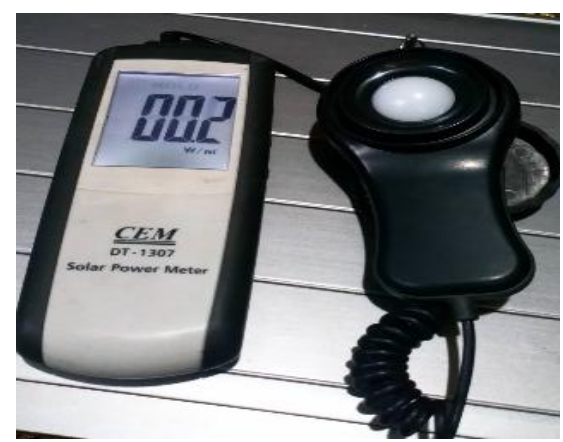

Fig. (5): Solar power meter.

The experiment was executed inside the solar energy Lab. of the Agricultural Engineering Department, Faculty of Agriculture, Ain Shams University (Latitude $30^{\circ} 06^{\prime} \mathrm{N}$, Longitude $31^{\circ} 14^{\prime} \mathrm{E}$ ). The experimental work was performed on the basin during four months of the year (January, 
February, March and April 2018) through different days. The following parameters were measured hourly for a period (from 8:00 am. to 6:00 $\mathrm{pm})$. All readings of temperatures, solar intensity were measured every 15 minute. Also, water productivity was measured every 60 minutes with graduated with 15000 and $35000 \mathrm{ppm}$ water salinity. Temperature variation, fresh water productivity and solar radiation per day for the modified solar still are presented and explained for different months. EC $\mathrm{PH}$ for three samples of water was carried out at central La, Faculty of Agriculture, Ain Shams University B.O.

Table (1): EC and PH for 3 samples of solar still water.

\begin{tabular}{|c|c|c|c|}
\hline & Salt water & Drink water & $\begin{array}{c}\text { Distillated water } \\
\text { for efficient design }\end{array}$ \\
\hline EC & Over $20000(\mathrm{ds} / \mathrm{m})$ & $0.50(\mathrm{ds} / \mathrm{m})$ & $\begin{array}{c}0.15 \\
(\mathrm{ds} / \mathrm{m})\end{array}$ \\
\hline PH & 9.06 & 7.69 & 7.42 \\
\hline
\end{tabular}

The thermal efficiency of the still $(\eta)$ was calculated using the equation given by (Tiwari 2002) as follows:

$$
\begin{gathered}
\eta=\frac{\text { Daily yield } * L}{A_{S} * \mathcal{E} \text { Is }(\mathrm{t}) * 3600} X 100 \\
\eta=\frac{5210 * 10^{-3} * 2.35 * 10^{6}}{1 * 6571.25 * 3600} X 100=51.8 \%
\end{gathered}
$$

Where: $\eta$ : is the thermal efficiency of the still, $L$ is the latent heat of vaporization at the saturation temperature $\mathrm{T}_{\mathrm{w}}$, (equal $2.35^{*} 10^{6} \mathrm{~J} / \mathrm{kg}$ ), As is area of solar still $\left(\mathrm{m}^{2}\right)$, and $\mathrm{Is}(\mathrm{t})$ is total solar intensity on the glass covers of solar still $\left(\mathrm{W} / \mathrm{m}^{2}\right)$.

\section{3- RESULTS \& DISSCUSION}

Fig. (6). Shows the effect of water salinity (15000 ppm and $35000 \mathrm{ppm}$ ) on the hourly distillate water. The results showed that the maximum value of distillate water rate was "493 mL and $437 \mathrm{~mL}$ " with salinity levels 
“15000 ppm and 35000 ppm" respectively at 2:00 pm in January. Due to, the solar radiation in this period is very high ant the ambient temperature.
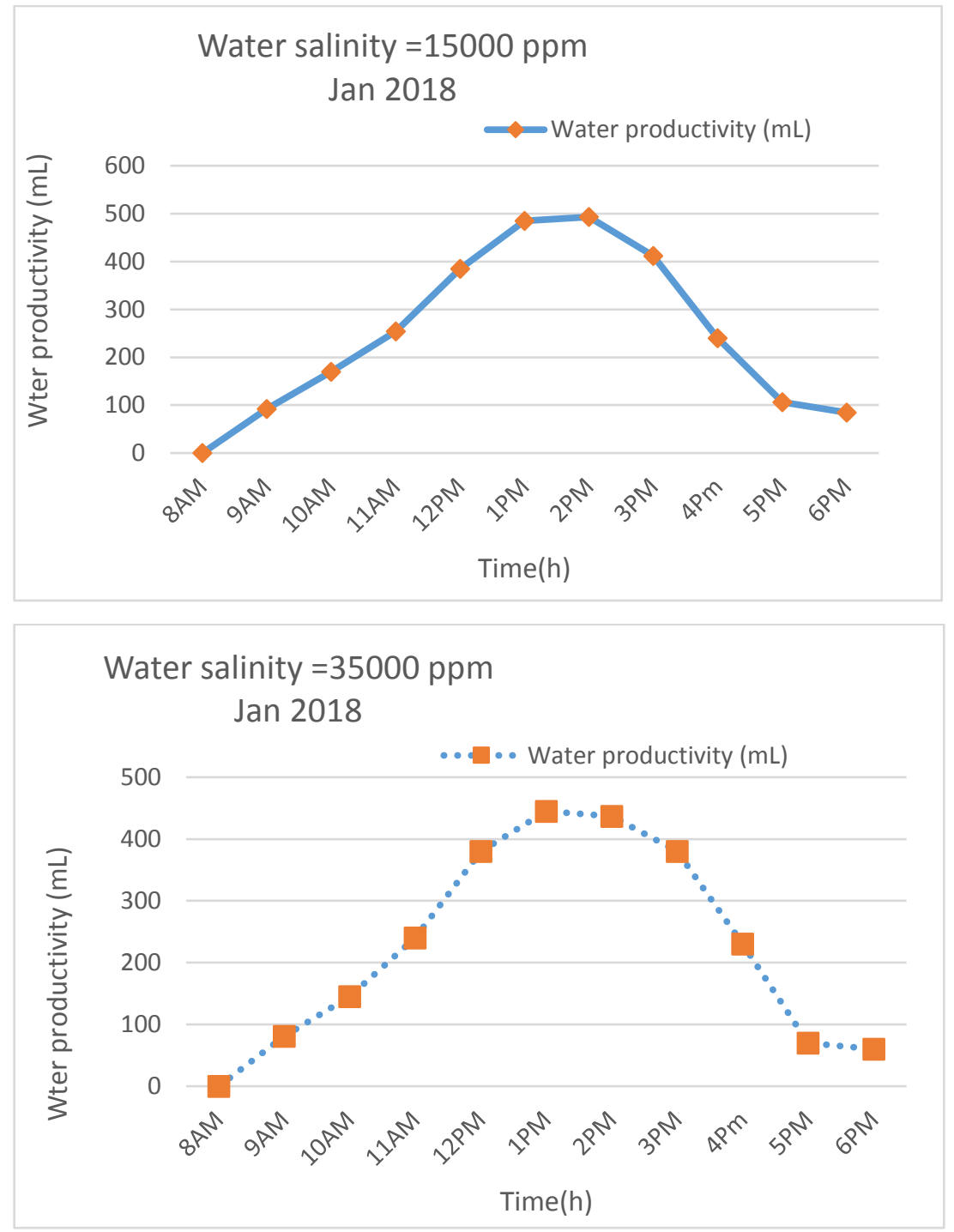

Fig. (6): Effect of water salinity on the hourly distillate water in Jan.

Fig. (7) Shows the effect of water salinity (15000 ppm and $35000 \mathrm{ppm})$ on the hourly distillate water. The results the maximum value of distillate water rate was $710 \mathrm{~mL}, 592 \mathrm{~mL}$ at salinity $15000 \mathrm{ppm}, 35000 \mathrm{ppm}$ respectively in February. 

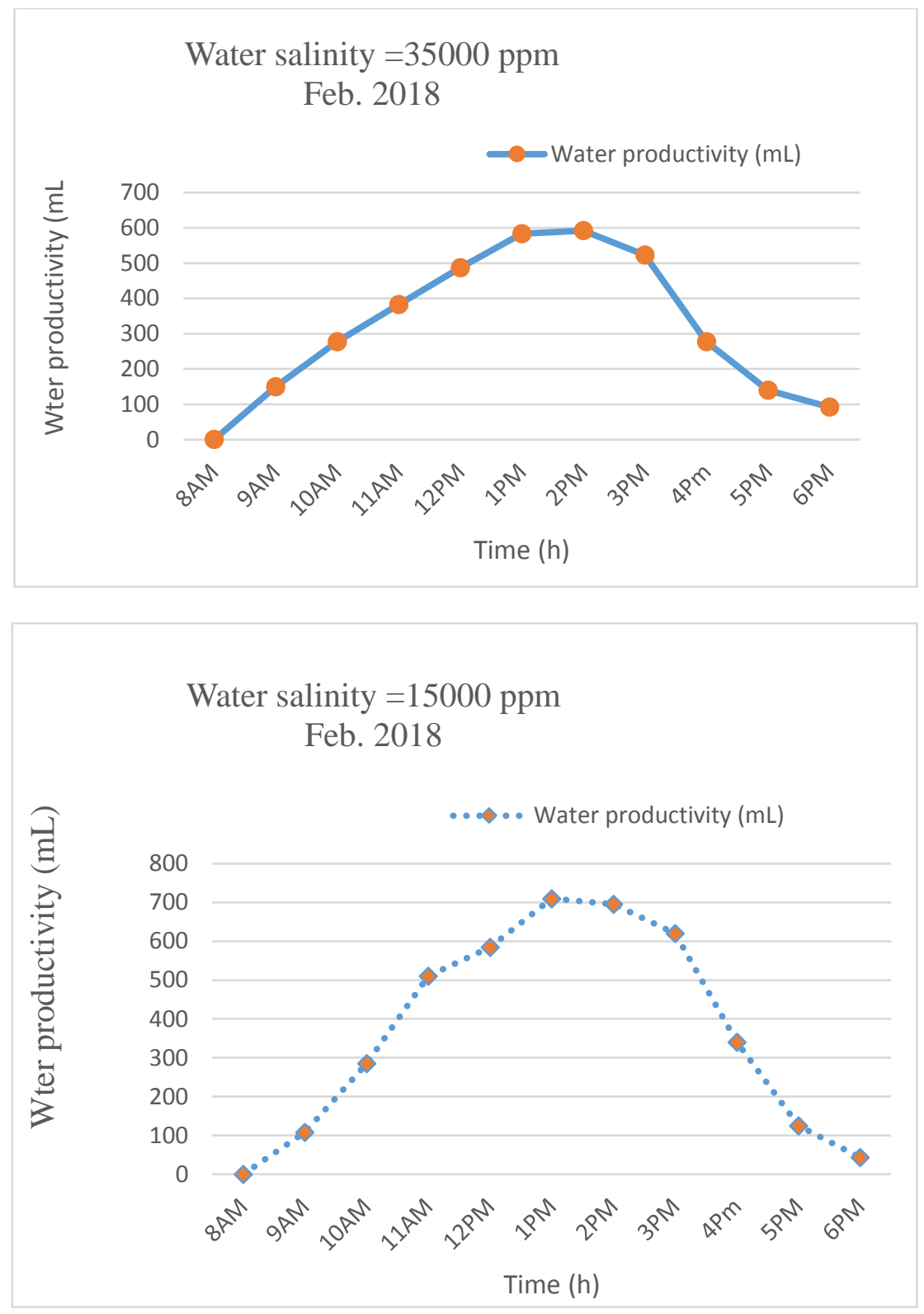

Fig. (7): Effect of water salinity on the hourly distillate water in Feb.

Fig. (8) Shows that effect of water salinity (15000 ppm and $35000 \mathrm{ppm})$ on the hourly distillate water. The results showed that the maximum value of distillate water rate was $720 \mathrm{~mL}, 710 \mathrm{~mL}$ at 1:00 p.m. with salinity 15000 ppm, 35000 ppm respectively in March. 


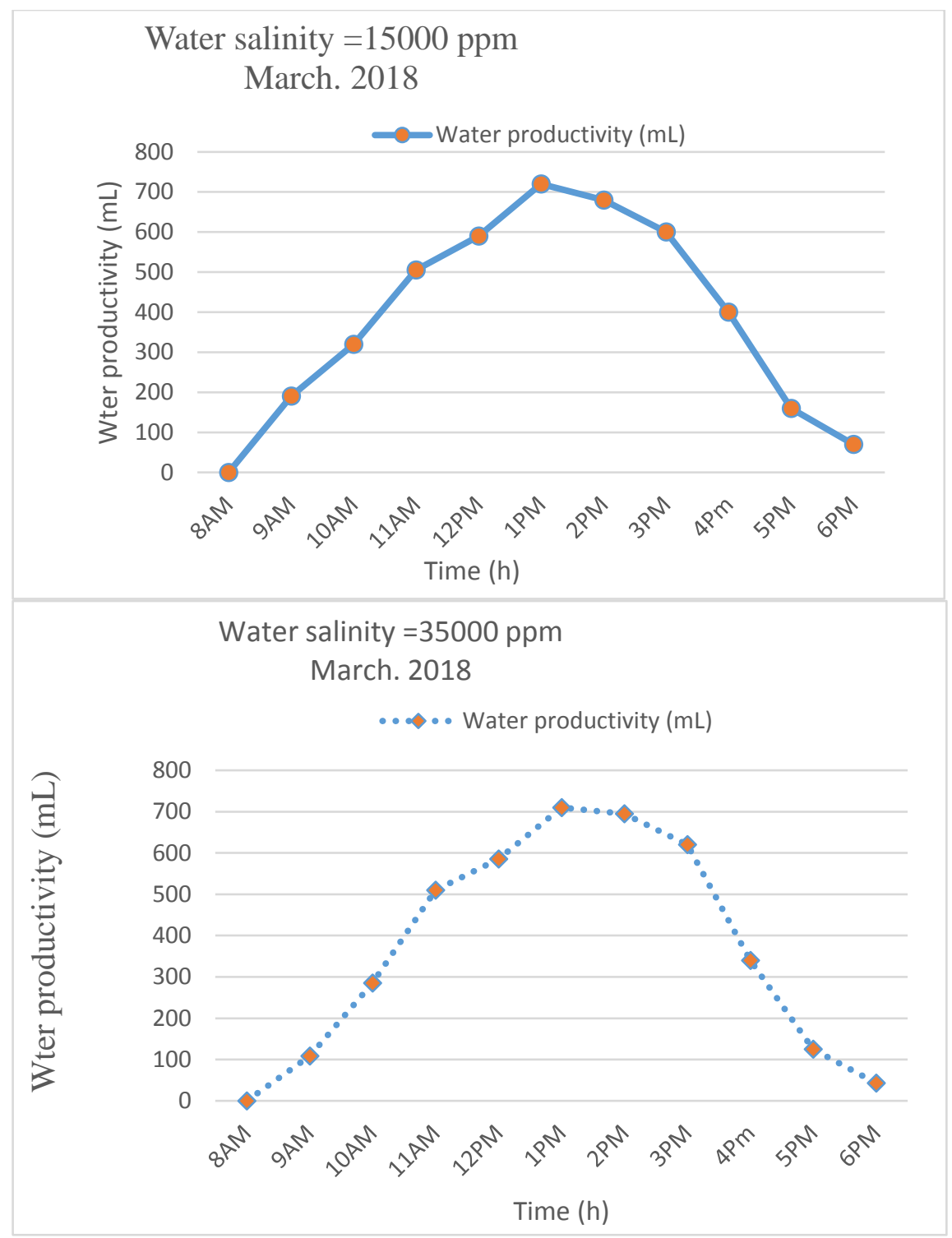

Fig. (8): Effect of water salinity on the hourly distillate water in March.

Fig. (9). Shows the effect of water salinity (15000 ppm and $35000 \mathrm{ppm}$ ) on the hourly distillate water. The results showed that the average distillate water attained its maximum value at 1:00 pm. The average distillate water remained its high at the afternoon hours this may be due to the accumulative and stored energy at this period compared to the rates before noon period. It is obvious that the highest value of distillate water 
rate is $870 \mathrm{~mL} / \mathrm{h}$ at water salinity of $15000 \mathrm{ppm}$ in April. On the other hand, the increase of water salinity from $15000 \mathrm{ppm}$ to $35000 \mathrm{ppm}$ was followed with a decrease in distillate water rate to $853 \mathrm{~mL} / \mathrm{h}$. The increase in water mass by increasing water salinity resulting in high thermal heat capacity then a reduction in evaporating rate may occur. This agrees with the results (Yazan 2012). Where he mentioned that the maximum distillate yield water obtained at the noon hour was $630.40 \mathrm{~mL}$ at salinity water of $15000 \mathrm{ppm}$.

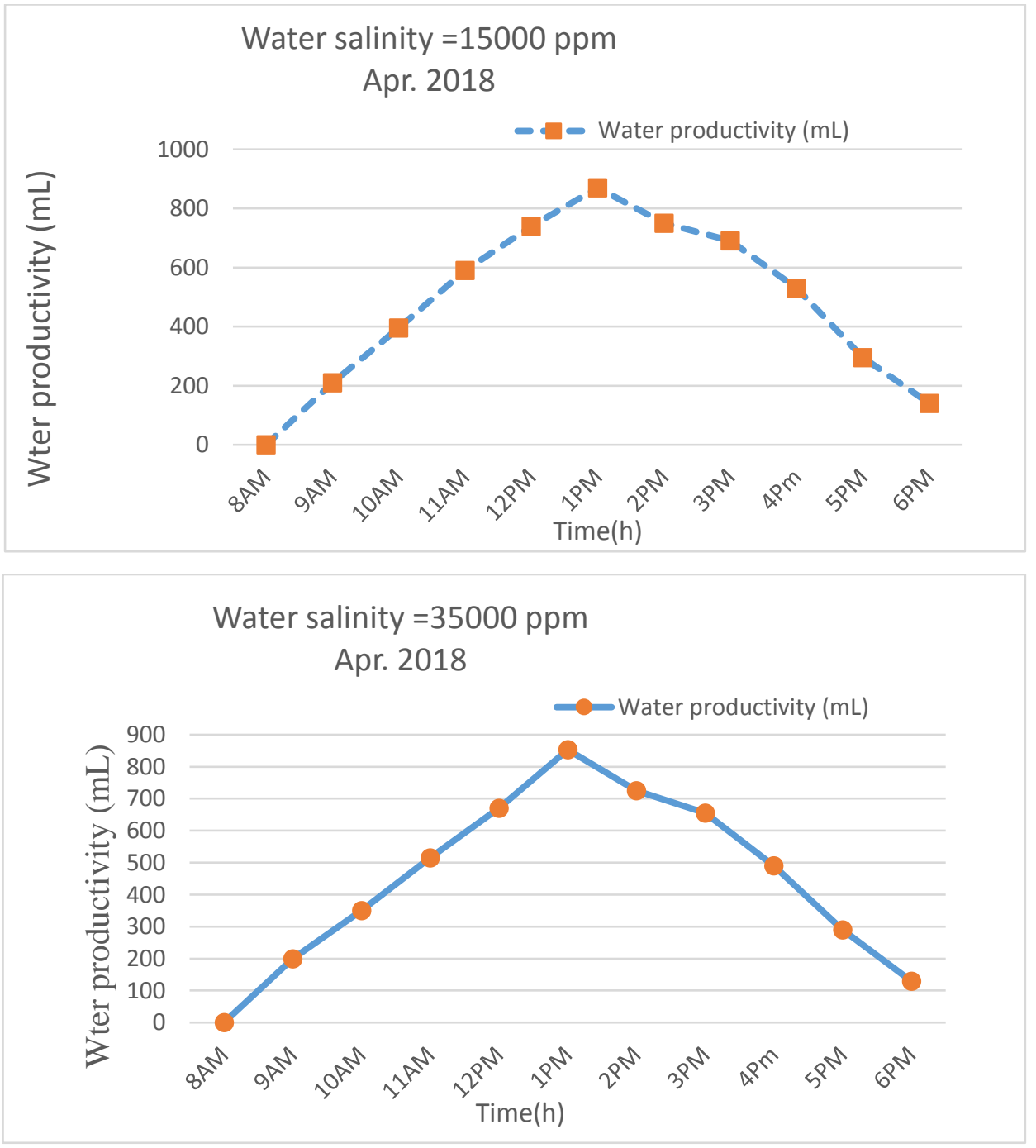

Fig. (9): Effect of water salinity on the hourly distillate water in April. 
The temperature changes per hour and solar radiation are shown in Figs. $10,11,12$ and 13. The results were that the value of solar radiation increased in the morning hours till it reaches the maximum value around noon hour, is then radiation value starts to decrease rapidly in period from afternoon to the sunset hours is .The ambient temperature increase with increase solar radiation. This agrees with the results (Yazan 2012). Where He said that the solar radiation and ambient temperature decrease in the morning and increase until the afternoon and then decrease solar radiation at sunset.

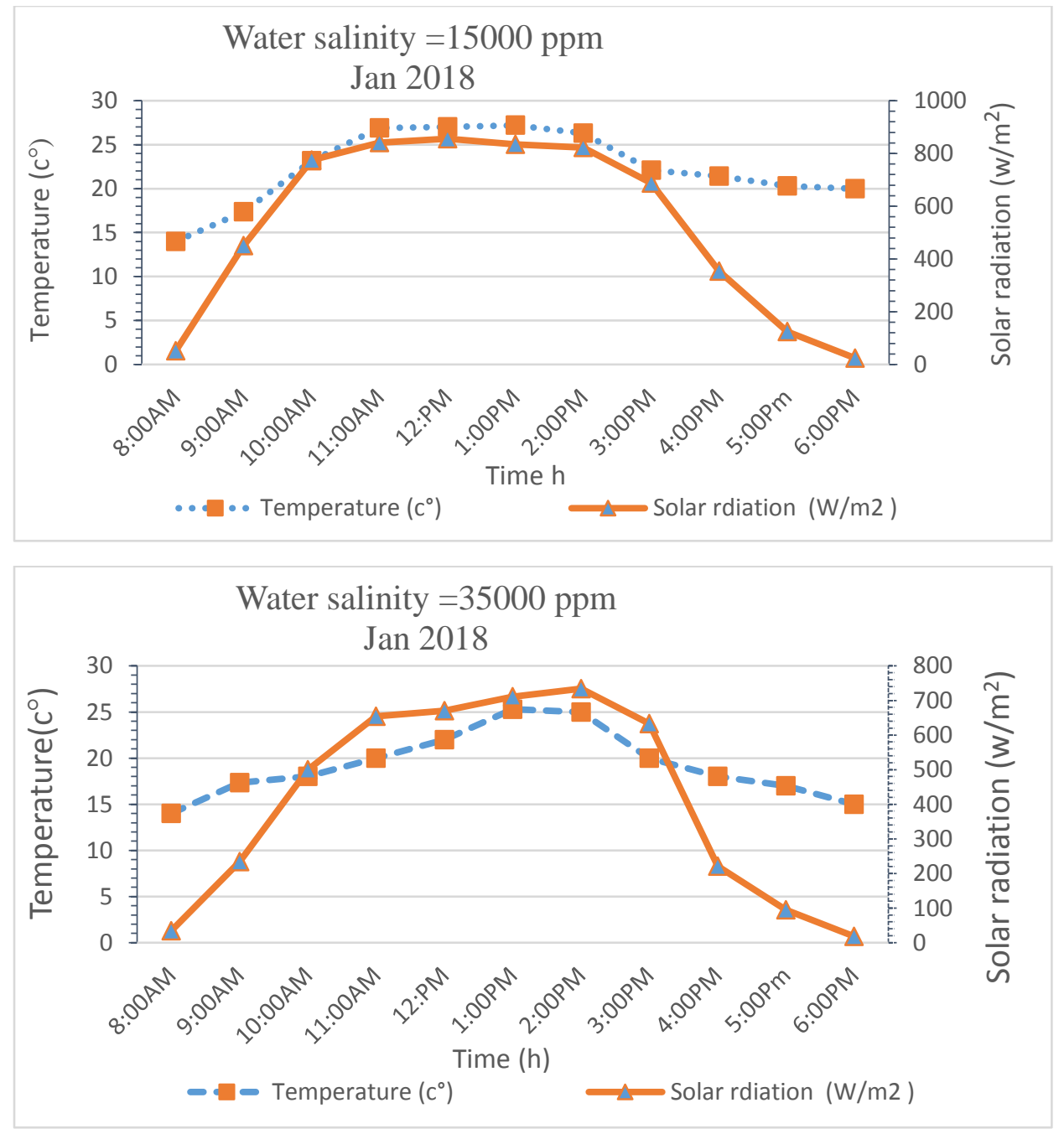

Fig. (10): Hourly variations of ambient temperature and solar radiation. 

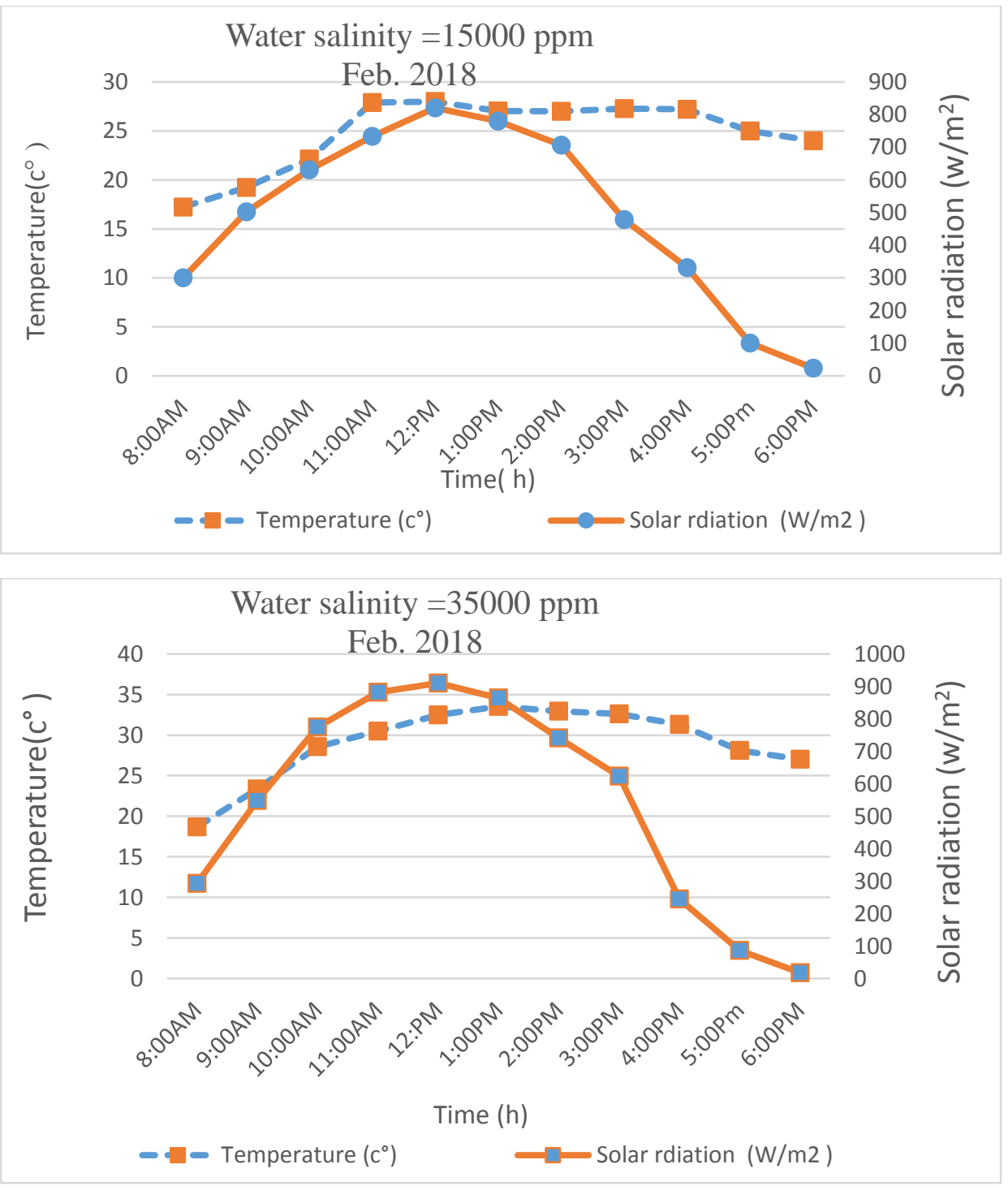

Fig. (11): Hourly variations of ambient temperature and solar radiation.

Changes in the productivity of distilled water every hour at temperatures in the outside atmosphere, on the wick, in the inner glass, and on the glass from the outside is shown in Figure (14). The results showed that the maximum values of $\mathrm{T}_{\mathrm{a}}, \mathrm{T}$ glass out, $\mathrm{T}$ glass in and $\mathrm{T}_{\text {wick }}$ are $37.9,68.7,74.7$, and $83.5 \mathrm{C}^{\circ}$ resp. at the $1 \mathrm{pm}$. due to, the solar radiation is very high in this period. 

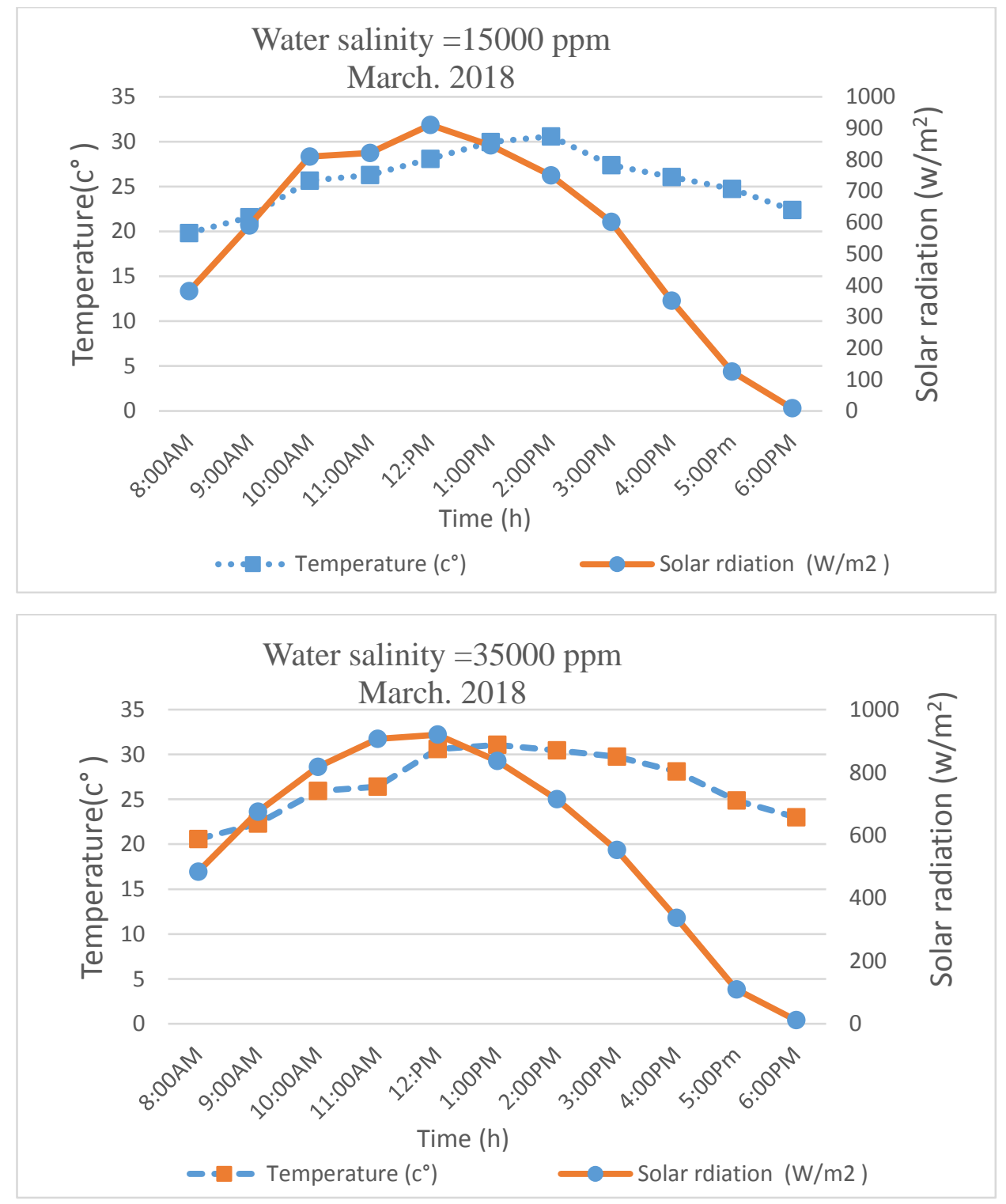

Fig. (12): Hourly variations of ambient temperature and solar radiation.

The average accumulated water productivity per months with salinity 15000, $35000 \mathrm{ppm}$ as shown in Fig. (15). The results showed that the maximum value of distillate water at salinity $15000 \mathrm{ppm}$ in Apr (5210 $\mathrm{mL}$ ). The minimum value of distillate water at salinity $35000 \mathrm{ppm}$ in Jan was $(2468 \mathrm{~mL})$. Due to, the solar radiation in this period was very high ant the ambient temperature. 

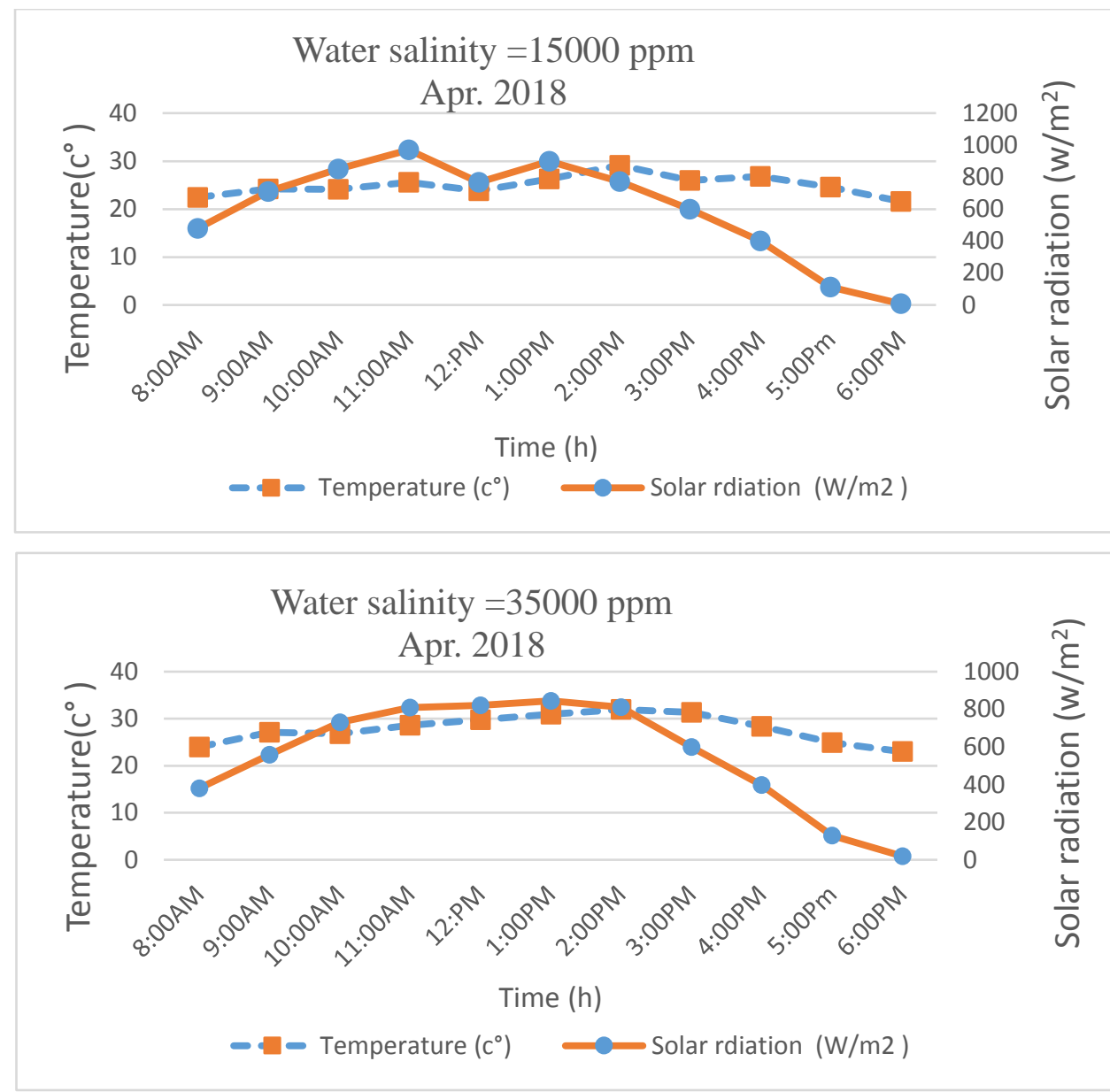

Fig. (13): Hourly variations of ambient temperature and solar radiation.

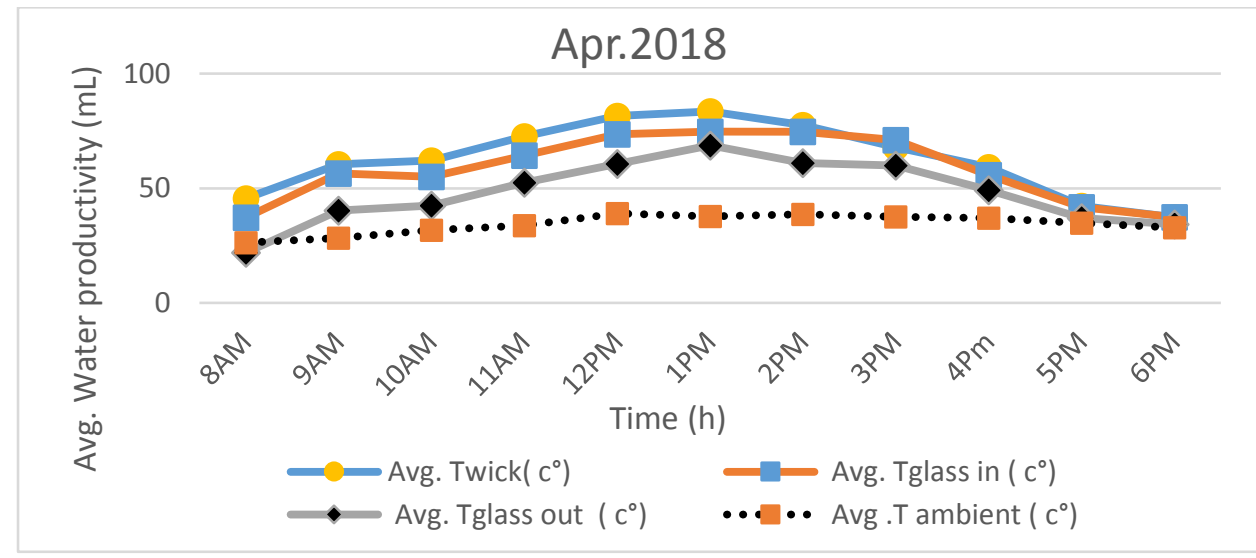

Fig.(14): Hourly variations of ambient, outer glass, wick and inner glass temperature. 
BIOLOGICAL ENGINEERING

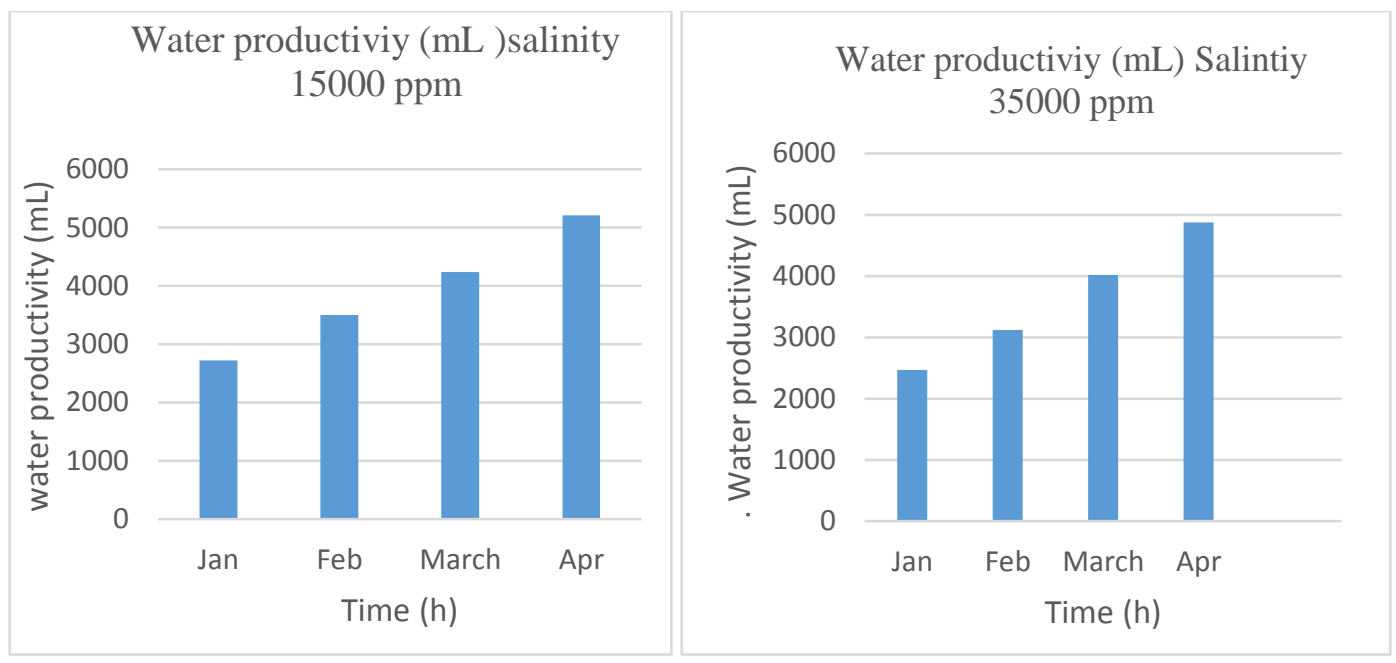

Fig. (15): The accumulated water productivity for months with salinity $15000,35000 \mathrm{ppm}$.

\section{5-CONCLUSSION}

The results showed that:

1- The maximum value of distillate water was obtained at salinity 15000 in April. While, the minimum value of distillate water was obtained at salinity $35000 \mathrm{ppm}$ in Jan. The average of distillate water in January was $2595 \mathrm{~mL}$.

2- The highest value of distillate water rate was $5210 \mathrm{~mL}$ in April at water salinity of $15000 \mathrm{ppm}$. While the minimum value of distillate water rate was $2468 \mathrm{~mL}$ in Jan.at salinity $35000 \mathrm{ppm}$. The average of distillate water in April was $5044 \mathrm{~mL}$.

3- The thermal efficiency of the solar still was $51.8 \%$.

\section{RECOMMENDATION}

\section{It is recommended that:}

1- Use the tilted wick in solar stills as it increases the efficiency and productivity of the still.

2- The saline water be fed to the wick to increase the productivity of distillate water.

3- Use a wick that has high absorptivity and diffusivity. 


\section{REFERENCES}

Alaian; W.M., Elnegiry, E.A., and Hamed, A.M.( 2016) Experimental investigation on the performance of solar still augmented with pinfinned wick. Desalination:379, 10-15.

EL. Dessouky; H.T., H.M. Ettouney (2002) Fundamentals of Salt Water Desalination of desalination, Elsevier,670.

Gupta; B., T. K. Mandraha, P. j Edla, M. Pandya (2013) Thermal Modeling and Efficiency of Solar Water Distillation, American Journal of Engineering Research (AJER):02, (12), 203-213.

Hansen; R.S., K.K. Murugavel (2017) Enhancement of integrated solar still using different new absorber configurations: an experimental approach, Desalination :422, 59-67.

Jani; H.K., K.V. Modi (2018) A review on numerous means of enhancing heat transfer rate in solar-thermal based desalination devices Renew. Sustain, EnergyRev:93,302-317.

Kalidasa; M ,K., K. Srithar (2011) Performance study on basin type double slope solar still with different wick materials and minimum mass of water, Renewable Energy:36, 612-620.

Kabeel, A. E. (2009). Performance of solar still with a concave wick evaporation surface. Energy:34,(10), 1504-1509.

Kabeel; A.E. , S.A. El-Agouz, (2011) Review of researches and developments on solar stills, Desalination :276, 1-12.

Mamlook; R., O. Badran, (2007) Fuzzy sets implementation for the evaluation of factors affecting solar still production:203, 394-402.

El-Naggar; M., A.A. El-Sebaii, , M.R.I. Ramadan, S. Aboul-Enein (2016) Experimental and theoretical performance of finned-single effect solar still. Desalin. Water Treat:57, 17151-17166.

Nayi; K., K. V. H. Modi (2018) Pyramid solar still: A comprehensive review. Renewable and Sustainable Energy Reviews:81, 136-148.

Sadhana; A.K., V., M. Kumar, A.K., V. R. Sachan , M. Kumar, G. Noida ( 2015) Experimental Study on a Finned Basin Solar Still, Int. J. Mech. Eng. Technol.:6, 16-20.

Abdel-Salam; M.F.M. (1998) Design of solar still for sea water desalination, Annals Agric. Sci., Sp. Issue 3, 613-643. 
Tiwari GN.( 2002). Solar energy: fundamentals, design, modelling and applications, Alpha Science Int'l Ltd.

\section{Velmurugan; V., K.J.N. Kumar, TN. H., K. Srithar (2009)}

Performance analysis in stepped solar still for effluent desalination, Energy:34, 1179-86.

Yazan; T., M.T. Madhar (2012) Performance of pyramid -shaped solar still: Experimental study,Desalination:291, 65-68.

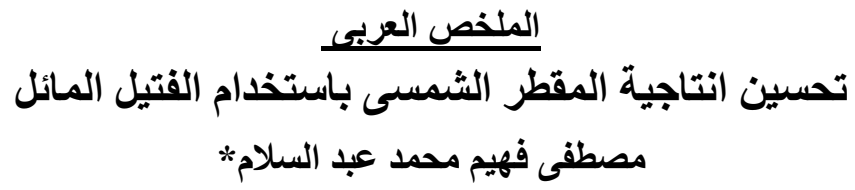

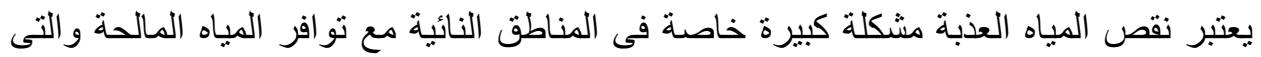

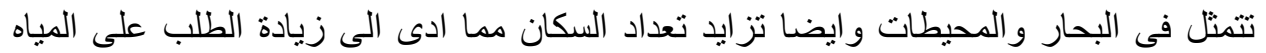

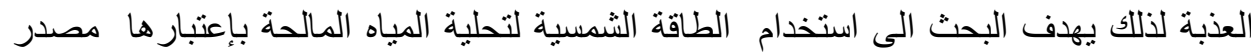

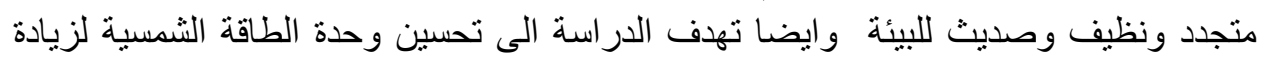

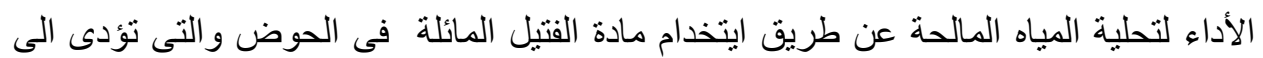

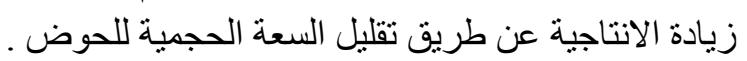

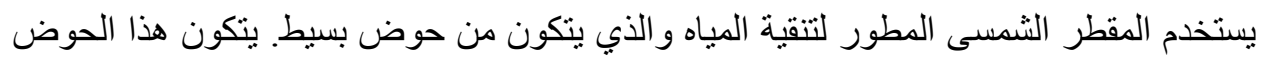

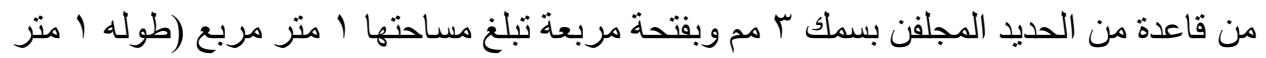

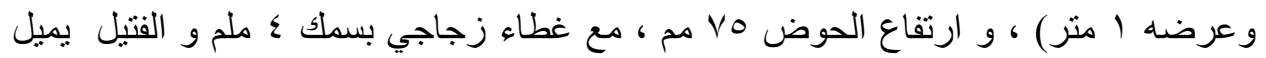

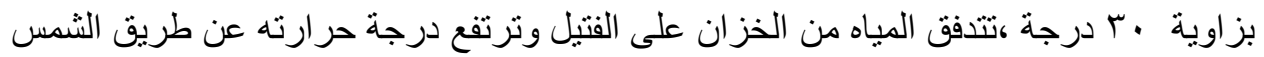

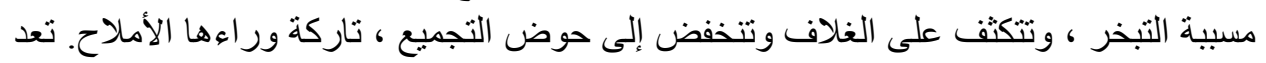

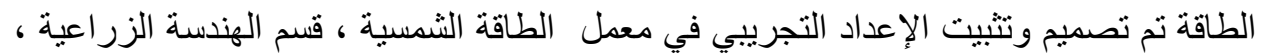

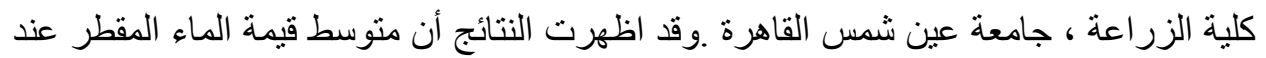

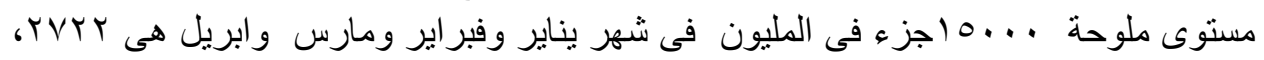

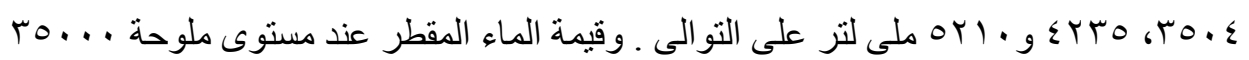

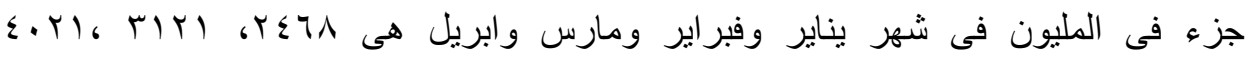

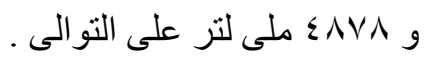
وتوصى الدراسة:

1 - بإستخدام مادة الفتيل وان تكون ذو امنصاصية وانتشارية عالية للماء المالح داخل المقطر الثمسي لزيادة الأنتاجية. r- سريان الماء المالح على الفتيل داخل المقطر يكون مناسب لمساحة الفتيل وحجم المقطر

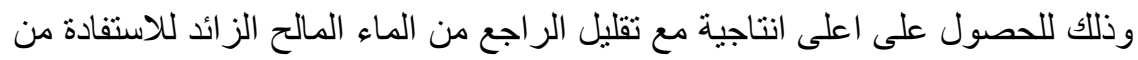
عملية التسخين والتبخير داخل المقطر . التطي

*أستاذ الهندسة الزراعية المساعد ـقسم الهندة الزراعية ـ كلية الزراعة - جامعة عين شمس. 